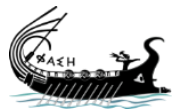

journal.phaselis.org

\section{Phaselis 2016 Yıllı Çalışmaları Işı̆ı̆nda Akropolis Özelinde Doğu Roma Dönemi Kent Planı ve Mimarisi Üzerine Ön Değerlendirmeler}

\author{
Pre-assessments on Eastern-Roman Era City Plan and \\ Architecture in the Light of Finds Obtained from the \\ Researches in Phaselis in 2016
}

Yalçın MERGEN

open access journals

The entire contents of this journal, Phaselis: Journal of Interdisciplinary Mediterranean Studies, is open to users and it is an 'open access' journal. Users are able to read the full texts, to download, to copy, print and distribute without obtaining the permission of the editor and author(s). However, all references to the articles published in the e-journal Phaselis are to indicate through reference the source of the citation from this journal.

Phaselis: Journal of Interdisciplinary Mediterranean Studies is an international peerreviewed journal and the articles which have had their peer reviewing process completed will be published on the web-site (journal.phaselis.org) in the year of the journal's issue (e.g. Volume II: January-December 2016). At the end of December 2016 the year's issue is completed and Volume III: January-December 2017 will begin.

Responsibility for the articles published in this journal remains with the authors.

Citation Y. Mergen, "Phaselis 2016 Yılı Çalışmaları Işığında Akropolis Özelinde Doğu Roma Dönemi Kent Planı ve Mimarisi Üzerine Ön Değerlendirmeler". Phaselis III (2017) 163-173. http://dx.doi.org/10.18367/Pha.16010

Received Date: 02.05.2017 | Acceptance Date: 28.06.2017 | Online Publication Date: 22.07.2017

Editing Phaselis Research Project www.phaselis.org 


\title{
Phaselis 2016 Yılı Çalışmaları Işığında Akropolis Özelinde Doğu Roma Dönemi Kent Planı ve Mimarisi Üzerine Ön Değerlendirmeler
}

\author{
Pre-assessments on Eastern-Roman Era City Plan and Architecture in the Light of Finds \\ Obtained from the Researches in Phaselis in 2016
}

\author{
Yalçın MERGEN*
}

Öz: Phaselis antik kenti 2016 yılında gerçekleştirilen Ortaçağ - Doğu Roma dönemi yüzey araştırması çalışmaları 2015 yılı çalışmalarının sonuçlarını destekleyen veriler sunmuştur. Bu kapsamda hem mimari hem de kent planına dair yeni sonuçlar elde edilmiştir. Özellikle kentin akropolünde yoğunlaşan çalışmalarla önceki yıllarda başlanan kent planı çalışmaları sürdürülmüş, daha önce bilinmeyen bazı yapılar ile kent planının bir kısmı belgelenmiş ve literatüre kazandırılmıştır.

Anahtar sözcükler: Phaselis, Lykia, Doğu Roma Imparatorluğu, Kent, Mimari, Orta Çağ

Abstract: Medieval and Eastern-Roman era surface survey studies held in 2016 have offered datas which support the results of surface survey studies of 2015. In this context, new results have obtained about both architectural and urban plan. Especially studies on urban planning started in the previous years have been continued with the studies concentrated in the city's acropolis. Some buildings which are not known before, and some part of urban plan have been documented and introduced into literature.

Keywords: Phaselis, Lycia, Eastern Roman Empire, City, Architecture, Middle Age

\section{Giriş}

Son yıllarda yapılan yüzey araştırmaları, Phaselis antik kentinin Lykia Bölgesi'nin Ortaçağ - Doğu Roma araştırmalarına önemli katkılar sağlayacak birikimlere sahip olduğunu göstermektedir. Phaselis'te söz konusu dönemlere dair elde edilen veriler, çevre kentlerle birlikte değerlendirilip analojik bir zemin oluşturulduğunda; Lykia Bölgesi özelinde ve taşra genelinde yerleşim tipolojisi, plan düzenlemesi, kentsel mekân ve mimari ilişkisi için hala cevap bekleyen sorunların çözümüne hem yüzey araştırmaları hem de kazılarla destek verecektir. Bu çalışma Phaselis antik kentinde gerçekleştirilen 2016 yılı yüzey araştırmaları sonucunda elde edilen bulguların ön değerlendirmesi niteliğindedir. Bu bulgular, çalışmanın birikimiyle doğru orantılı olarak daha detaylı bir biçimde ele alınacaktır.

Phaselis antik kentinde yürütülmekte olan yüzey araştırması çalışmalarının bir bölümü de kentin, Erken Hıristiyanlık ve Doğu Roma dönemlerine yönelik planlanan araştırmaları kapsamaktadır. Bu çerçevede, 2016 yılı çalışma sezonunda öncelikli olarak, 2014 yılında başlatılan ve 2015 yılında da sürdürülen 'akropolis' çalışmalarının devamılı̆̆ı hedeflenmiştir ${ }^{1}$. Çalışmadaki

\footnotetext{
Öğr. Gör. Dr., Dokuz Eylül Üniversitesi, Güzel Sanatlar Fakültesi, Temel Eğitim Bölümü, Sanat Kuramları Anasanat Dalı, İmir.ymergen68@gmail.com

${ }^{1}$ Phaselis kentinde 2014 ve 2015 yılında sürdürülen çalışmalar için bkz. Arslan - Tüner Önen 2015a, 198-207;
} 
öncelikli amaç, kentin bu bölgesinde yar alan, özellikle Doğu Roma - Erken Hıristiyanlık ve Doğu Roma dönemlerine ait yapı stoklarını tespit etmek, topoğrafik kent planına aktarmak ve bunlara bağlı olarak da kent planını ve yerleşim kronolojisini açıkığa kavuşturmaktır. Ayrıca Phaselis antik kentinin erken dönemlerden başlayarak nasıl bir dönüşüm süreci geçirdiğini anlamak, oryantasyon çeşitliliklerini tanımlamak, yapı tipleri ve inşa evrelerini belirlemek çalışmanın diğer amaçlarını oluşturmaktadır.

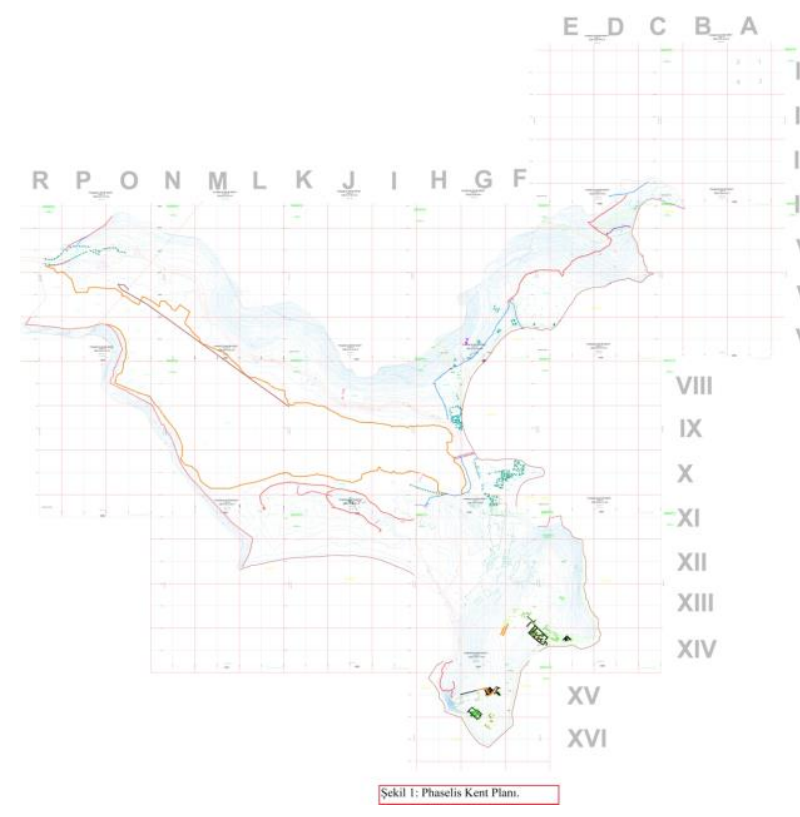

Fig. 1. Phaselis Topoğrafik Kent Planı

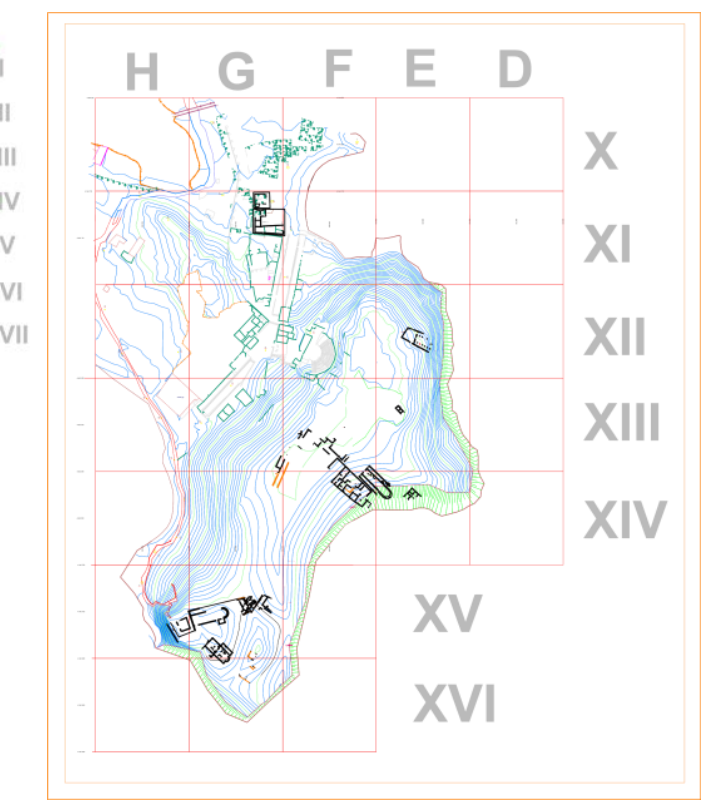

Fig. 2. Akropolis Topoğrafik Planı

Phaselis antik kentinin kurulum plânı, kentin bulunduğu coğrafik biçimlere uyumlaştırılarak düzenlenmiştir. Bu durumun erken dönemlerinden başlayarak, kentin terk edildiği zamana kadar korunduğu anlaşılmaktadır (Fig. 1). Ayrıca, Phaselis'in kentsel mekân düzenlemesinin Erken Hıristiyanlık ve Doğu Roma dönemlerinde de klasik kent anlayışına sadık kalınarak sürdürüldüğü izlenmektedir. Bu nedenlere bağlı olarak, Phaselis'in kentsel yapısı temel olarak 'aşağı kent' ve 'akropolis' şeklinde iki ana mekâna ayrılarak tanımlanmaktadır. Kentin büyük bir kısmının yayılım gösterdiği, denizle dolaysız ilişkisi olan 'aşağı kent' ve deniz seviyesi ile yerleşimin diğer birimlerinden yer yer +25 ila +30 m kot farklılığı olan 'akropolis' ana ve belirleyici birimleri oluşturmaktadır. Phaselis'in Akdeniz ile yapısal ve düzenlenmiş ilişkisini sağlayan 'liman birimleri' ise kuzey, orta ve güney liman olarak tanımlanmaktadır. Ayrıca Phaselis'in geniş ölçekli nekropolisleri de kent bünyesinin karakterini oluşturup özgün kılan önemli unsurlarıdır. Bunların dışında kent çok geniş bir teritoryuma sahiptir.

Yukarıda sayılan özellikler nedeniyle çalışma iki farkı dilimde gerçekleştirilmiştir. Bunların ilki önceki sezonlarda kent planının anlaşıması amacıyla başlanmış olan topoğrafik kent planının 'akropolis' merkezli olarak tespiti ve sayısal ortama aktarılmasıdır. Diğeri ise kentin teritoryumunda bulunan ve kentle ilişkili sosyo-kültürel ve ekonomik bütünlüğü sağlayacak olan verilerin toplanması amacıyla yapılan yüzey tespit çalışmalarıdır.

Bu iki alan iki farklı çalışma sistemini gerekli kılmaktadır. Bunların ilki, kent içinde yapılan çalışmalar için geliştirilen ve sayısal harita üzerinde görselleştirilen sektörel birimlerdir (Fig. 1).

2015b, 69-80; 2016a, 236-246; 2016b 355-368. 
Sektörel kareleme sistemi memleket koordinatlarına göre hazırlanmış olan ve araştırma başkanı̊̆ının gayretleriyle sağlanan sayısal topografik kent planına uygulanmıştır. Önceki yıllarda Phaselis kenti sınırlarında yapılacak tespit çalışmalarının sağlıklı olabilmesi için oluşturulup geliştirilen bu sistem 2016 yılında da kullanılmaya devam etmiştir. Phaselis antik kenti sayısal topoğrafik haritası üzerinde ve gene sayısal olarak geliştirilen sektörel kareleme sistemi aynı

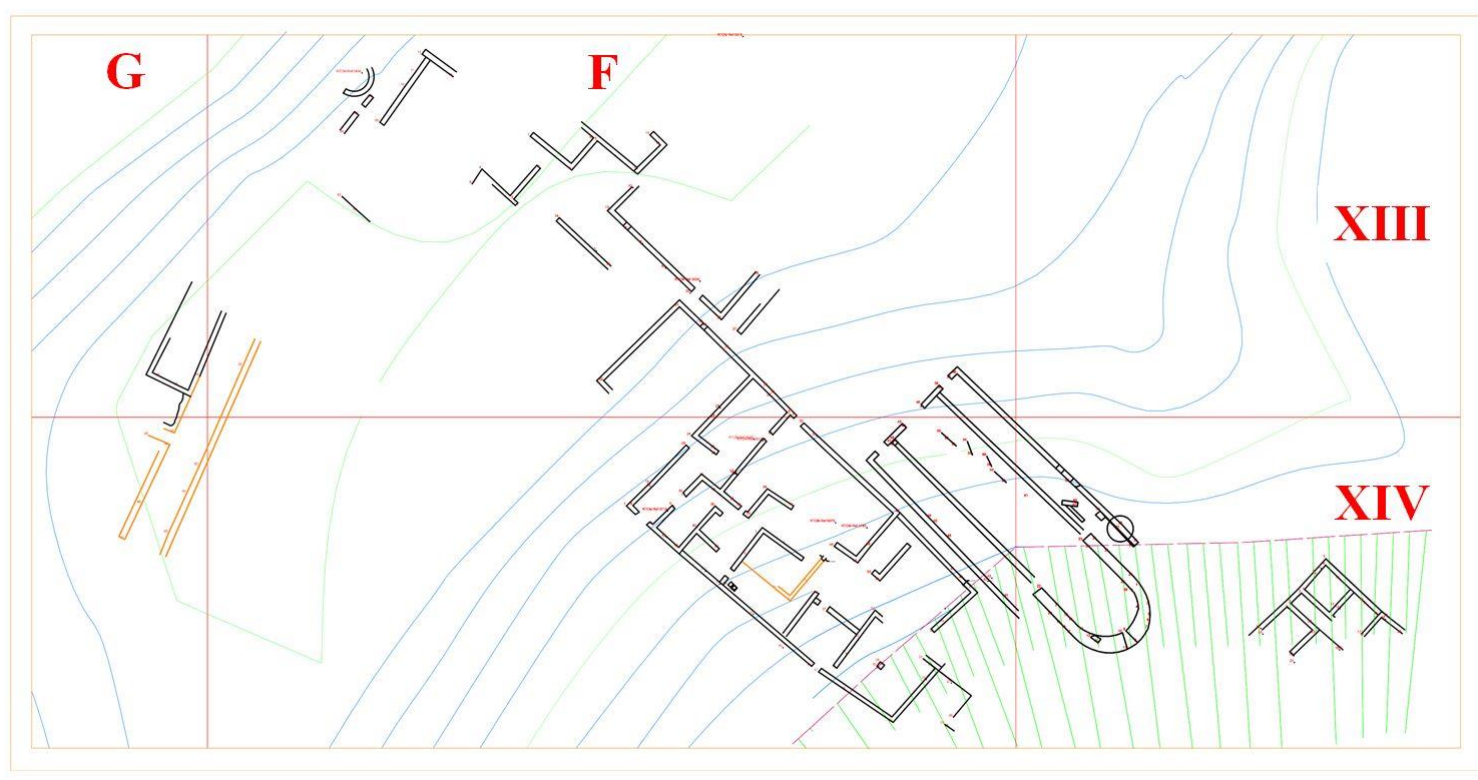

Fig. 3. Akropolis F, G - XIII, XIV Sektörlerinde Tespit Edilen Mimari Bulgular

zamanda, gelecekteki olası kazı çalışmalarına yönelik düzenlemeler de içermektedir. Koordinat sistemine göre $100 \times 100$ metre ölçülerindeki sektörler, $50 \times 50$ m ölçülerinde 4 parçaya ayrılmıştır. Her bir $50 \times 50$ metrelik birim kendi içinde $10 \times 10$ metrelik karelere bölünerek arkeolojik kazı teknikleri açısından kullanılabilir bir adresleme sistemi geliştirilmiştir (Fig. 1, 2). Bu sistem aynı zamanda kazı alanlarının karolaj sistemine uygun biçimde oluşturulması adına aplikasyonu yapılabilir reel değerler içermektedir.

Kent içinde ve teritoryumunda yapılan tespit çalışmalarında, 'Leica Viva GS14 GNSS - GPRS cors' cihazı kullanılmıştır. Tespit edilen yapı ve kalıntıların hem lokasyonları hem de ölçekli plan çizimleri için gerekli ölçüler $0,5 \mathrm{~cm}$ hassasiyet sağlayan bu cihazla, koordinat sistemine uygun biçimde harita üzerine süperimpoze edilecek şekilde alınmıştır (Fig. 10). Ayrıca bir hataya mahal vermemek için alınan noktalar Professional Mobile Topographer StgrDev programı ile sınanmış ve yerleştirilmiştir. Yapılan çalışmalar sırasında Bakanlık yönergesi gereği WGS84 koordinat sistemi kullanılmıştır. Phaselis antik kentine ait sayısal topoğrafik kent plânı ise ITRF96 koordinat sistemine göre düzenlenmiştir. Bu nedenle belirlenen buluntuların sayısal harita üzerinde görülen sektörlere doğru yerleştirilebilmesi için ITRF96 koordinat sistemine göre alınan koordinatların WGS84 koordinat sistemi değerlerine dönüştürülmesi işi de ekibimiz tarafından gerçekleştirilmiştir.

\section{Phaselis Antik Kenti Akropolisinde Tespit Edilen Yeni Bulgular}

Phaselis akropolisinde yapılan tespit çalışmaları sırasında ve 2016 yılı çalışma sezonunda önceki yıllara ek olarak bazı yeni verilere ulaşmanın dışında, önceki yıllarda görülen ve çalışmalarına başlanan bazı yapıların plan ve topoğrafik plana eklenmesi çalışmaları sürdürülmüştür. Bu bağlamda 2016 yılı çalışmaları G / XV - XVI, F / XIII - XIV, G / XIII - XIV sektörlerinde yoğunlaştırılmış- 
tır (Fig. 2). Çalışma alanının kendine özgü zorlukları nedeniyle, F - XIV sektöründe var olduğu anlaşılan ve $1 n^{0}$.'lu konutun hemen güneyinde yer alan bir başka yapıda da çalışmalar yürütülmüştür. Büyük boyutlu bir konut olduğu kuvvetle muhtemel olan bu mekânlar topluluğu, 2017 yılı çalışma sezonunda plan çalışmaları yapılacak ve topoğrafik haritaya eklenecek düzeyde incelenmiştir.

\section{$1 \mathrm{n}^{0}$.'lu Konut Kompleksi}

2015 yılında görülen ve adlandırılan $1 \mathrm{n}^{0}$.'lu konutun (Fig. 4) aslında çok daha büyük boyutlu ve karmaşık mekânlar topluluğuna sahip olduğu yapılan yüzey çalışmaları sırasında anlaşılmıştır. Bu nedenle söz konusu konut yeniden değerlendirmeye alınmıştır. Bitki örtüsünün çok sık ve geçit vermez durumuna rağmen yapının mekânları ve birbirleriyle olan organik ilişkileri saptanabilmiştir.

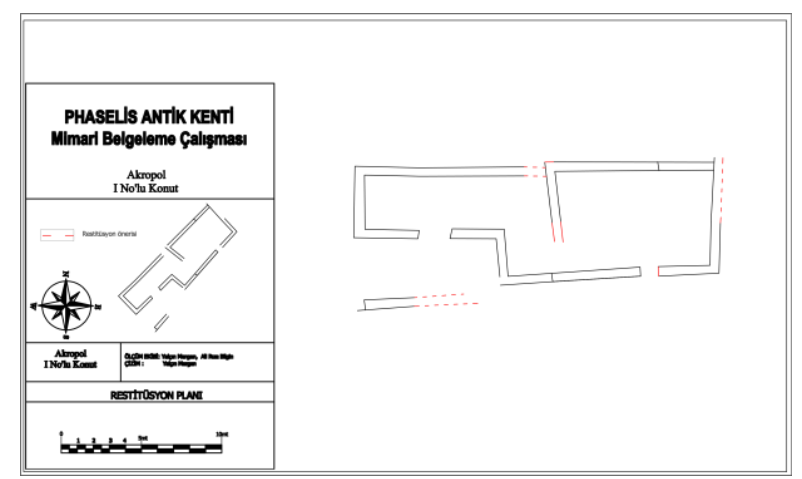

Fig. 4. $1 n^{0}$.'Iu Konut 2015 Yılında Elde Edilen Sonuç

1 n'.'lu konut, akropolisi teşkil eden yarımadanın yaklaşık doğusunda, Akdeniz'e bakan yarların üzerinde ve F / XIII - XIV sektör sınırları içinde yer almaktadır (Fig. 2, 3). Yapının kuzeydoğusunda ve hemen bitişiğinde 2015 yılı çalışma sezonunda belgelenen ve $3 \mathrm{n}^{\circ}$. ile adlandırılan kilise bulunmaktadır ${ }^{2}$ (Fig. 2). Bu iki yapının organik bir ilişkiye sahip olup olmadığı henüz kesin olarak anlaşılamamış olmakla beraber, inşa evre ve tekniklerinin aynı olduğu, bu nedenle de çağdaş oldukları söylenebilir.

Konut kompleksinin yüzeydeki kalıntılara dayalı olarak farklı ebat ve işlevleri olan 16 adet mekâna sahip olduğu anlaşılmaktadır (Fig. 6). 1 no.'lu konut kompleksi $61 \times 21 \mathrm{~m}$ ölçülerindeki bir alan üzerinde yer almaktadır. Söz konusu 16 mekân içerisinde işlevi net olarak anlaşılabilen 4 adet mekân bulunmaktadır. Bunlardan ' $m 1$ ' ve ' $m 15$ ' in avlu olması kuvvetle muhtemeldir. Bununla beraber her iki avlunun işlevinin farklı olduğu ' $\mathrm{m} 15$ ' in barındırdığı bazı yapısal izlere bağlı olarak söylenebilir. Diğer iki mekândan biri yani ' 8 ', mekân topluluğunun su ihtiyacını karşılayan sarnıç birimi, 'm14' ise çok katlı gündelik yaşam birimidir. İ̧̧levi konusunda açık veriler olmasa da, ' $m 5$ ' in kuzey batısında yer alan birimin de çok katlı olduğunu söylemek duvar kalıntılarının yüksekliği ve duvarlarda görülen hatıl sıralarına ait yuvalar sayesinde mümkün olmaktadır.

Bölgede yapılan çalışmalar ışı̆̆ında, Lykia Bölgesi'nde uygulanan konut mimarisinin olasılıkla yerleşim alanlarının kısıtlaması nedeniyle çok katıı olarak tercih edildiği anlaşılmaktadır ${ }^{3}$. Özellikle

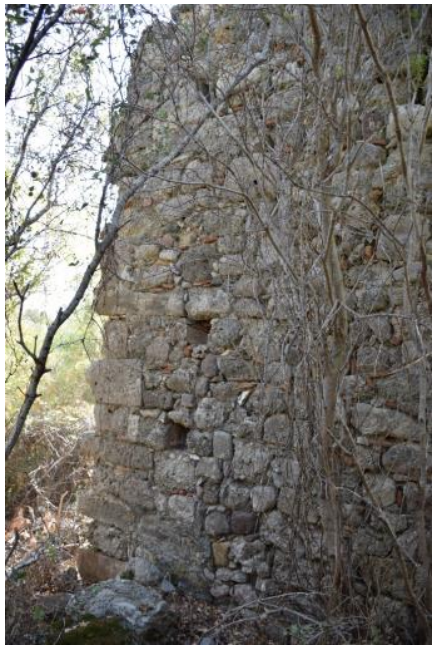

Fig. 5. $1 \mathrm{n}^{0}$.'lu Konut 14 Numaralı Mekân Güneybatı Duvar Dış Cephe

3 numaralı kilise çalışma ve değerlendirmeleri için bkz. Mergen - Bilgin 2016.

Lykia Bölgesi'nin Erken ve Geç Roma dönemleri önemi konut mimarisi konusunda en önemli ipuçları Beymelek (Mcnicoll - Winikoff 1983), Kyenai (Kolb 1996, 1998) ve Olympos'ta (Mergen 2011) yapılan çalışmalarla ortaya konmaktadır. Bu kentlerde de konut mimarisi açısından elde edilen veriler çok katı kule 
Olympos'ta son yıllarda yapılan çalışmalarla, akropolis tepesinde bulunan ve günümüze büyük ölçüde sağlam ulaşan bazı örnekler hem kule tipi konutların Lykia Bölgesi'ndeki varlığını hem de yerleşim seçeneklerinin değerlendirme ölçütlerini ortaya koymaktadır ${ }^{4}$. Bu tipte ve birkaç kattan oluşan kule evler Ege bölgesinde konut olarak günümüze kadar kullanılmaya devam etmiştir. Ege Bölgesi Yeni Foça civarındaki kule ev düzenleme geleneği Doğu Roma ve Doğu Roma öncesine dayanan konut mimarisinin bir devamı olarak düşünülmektedir ${ }^{5}$.

Ege bölgesinde tarım arazilerinin yakınında kurulu kule evlerin, dar mazgal pencerelerle aydınlatılmış alt katları bir çeşit depolama amacı ile kullanılmıştır. Bazen üst bazen de orta katta bulunan ocak nişi, evin bu bölümlerinin mutfak ve günlük işlerin görüldüğü yerler olduğunu göstermektedir ${ }^{6}$. Kulelerde iç hacim ahşap bölüntülerle katlara ayrılmış, üst katlara çıkış mekânın bir köşesine yerleştirilen ahşap merdivenlerle sağlanmıştır. Genelde zeminden çatıya kadar yükselen bir direk, tavanı taşıyan kirişlere destek olmaktadır.

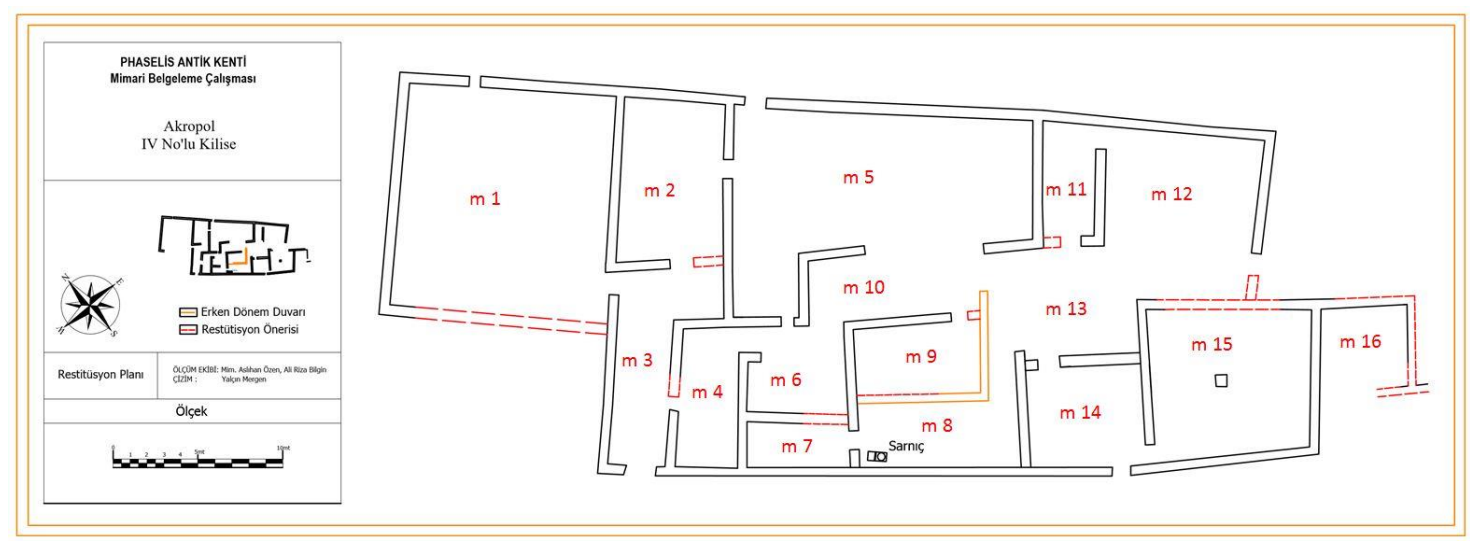

Fig. 6. 1 n’lu Konut Ölçekli Restitüsyon Planı

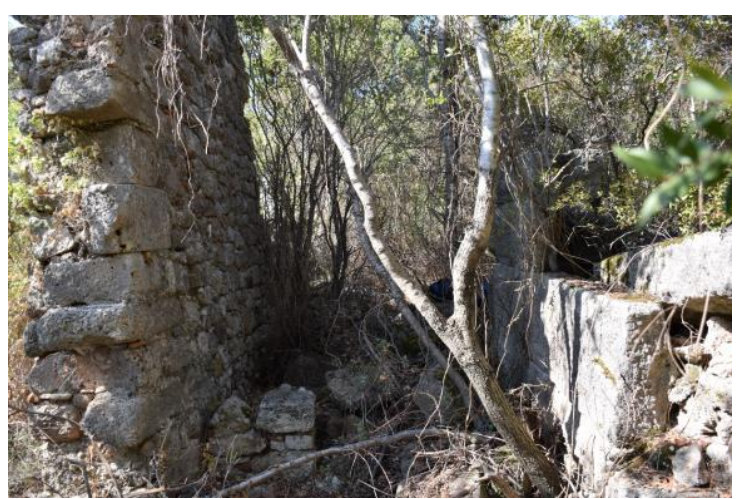

Fig. 7. $1 \mathrm{n}^{0}$.'lu Konut 14 ve 9 Numaralı Mekânlar Arasında Yer Alan Koridor ve Erken Dönem Duvarı

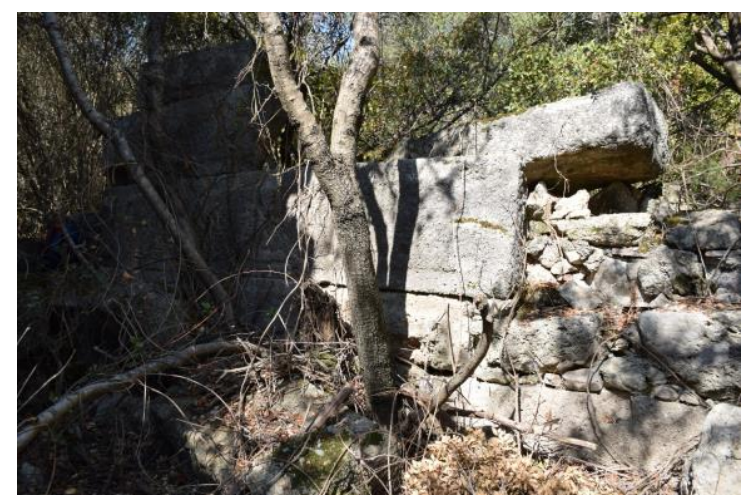

Fig. 8. 1 nº'lu Konut 9 Numaralı Mekânı Doğuda Sınırlayan Bosajlı Erken Dönem Duvarı

$1 \mathrm{n}^{0}$.'lu konut Phaselis akropolisinin dönemler arası geçiş sürecinin yapısal olarak izlenebildiği ve şu ana kadar tespit edilmiş en iyi örneklerinden birisidir. Bunun nedeni, 'm2' ye ait kuzeydoğu

tipi evlerin ve çiftliklerin varlığını göstermektedir. Bununla beraber kule tipi çiftliklerle kentsel planlama içinde yer alan kule tipi evler arasında biçim açısından benzerlik olsa da işlev açısından benzerlik bulunmamaktadır. Kule tipi çiftliklerin özellikleri için bk. Konecny 1997.

4 Mergen 2011, 467.

5 Kule evlerin plân ve işlev özellikleri için bk. Arel 1990, 43-71; 1993, 37.

6 Arel 1990, 44. 
duvarının alt kottaki bölümünün, 'm9' batı ve doğu duvarlarının üst kotlarda izlenebilen bölümlerinin erken döneme ait olmasıdır. Özellikle ' $m 9^{\prime}$ da görülen duvarlar tamamen in situ, bosajı ve özgün dönemlerine ait bir adet açıklığa sahiptir (Fig. 6, 7, 8, 9). Geç dönem duvarları ise bu duvarların üzerine inşa edilmişlerdir. Bununla beraber, ' $m 8$ ' içinde ve batı köşede yer alan sarnııın da erken dönemlere ait olduğu ve kullanımının geç dönemde de devam ettiği mekânı çevreleyen duvarlar nedeniyle anlaşılmaktadır ${ }^{7}$ (Fig. 6).

1 n'.'lu konut olarak adlandırılan mekânlar topluluğunu kuzey - kuzeydoğu yönünde sınırlayan duvarın alt kottaki bölümü ile 'm9' u sınırlayan duvarların akslarının yaklaşık dik olması ve $1 n^{0}$.'lu konutun geç döneme ait duvarlarının en azından mekânları kuşatan cephe duvarının bu özelliğine uyumlaştırılarak ve direkt erken dönem duvarları üzerine inşa edilmiş olması akropolis için önem taşımaktadır. Bunun nedeni elde edilen sonucun akropolis açısından hem yüzeyde görülemeyen erken dönem yerleşimi planına ilişkin veri sunması dışında, geç dönem yerleşiminin plan uyumlaştırması ve stratejisi açısından da bilgi sunmasıdır.

Söz konusu mekân topluluğunun Doğu Roma evresinde moloz, kaba - yontu kesmetaş ve devşirme kesmetaş kullanılımıştır. Bağlayıcı malzeme ise kireç harcıdır. Duvarların sıvandığı anlaşılmaktadır (Fig. 5, 7).

\section{Yapı Adaları ve Sokak}

$1 n^{0}$.'lu konut çalışmaları sırasında ve bu yapıya

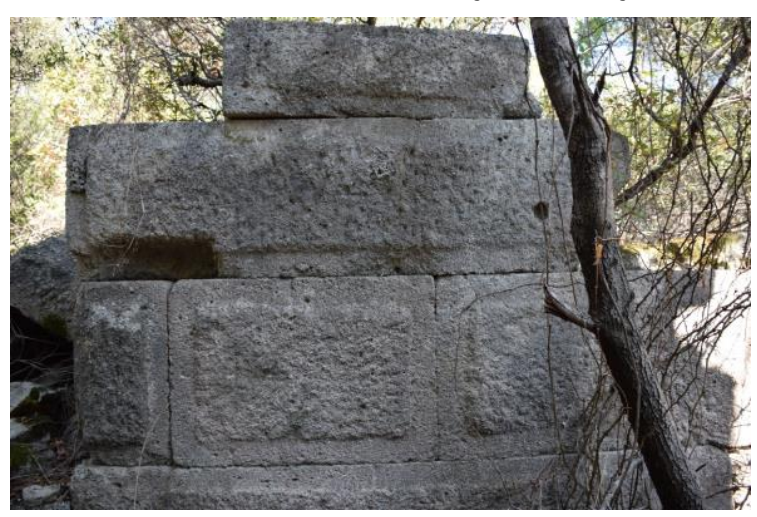

Fig. 9. $1 n^{\circ}$.'lu Konut 9 Numaralı Mekânı Doğuda Sınırlayan Bosajlı Erken Dönem Duvarı ve Pencere veya Kapı Açıklığı ait ' $m 1$ ' olarak adlandırılan avlunun kuzeydoğusunda F - XIII sektöründe bazı duvarlara rastlanmış ve bu duvarlar da topoğrafik kent plânına dâhil edilmişlerdir (Fig.2, 3, 10). Söz konusu duvarlar $3 \mathrm{n}^{0}$.'lu kilise ve $1 \mathrm{n}^{0}$.'lu konutun bulunduğu alan ile akropolisin batısındaki dik yamaca doğru kuzeybatı - güneydoğu aksında yöneliş gösteren bir sokağı sınırlamaktadırlar (Fig. 10). Duvarların sınırladığı mekânlar, yıkıntı ve bu yıkıntıdan kaynaklı moloz yığınları nedeniyle bütünlüklü olarak tanımlanamamaktadır. Bununla beraber şimdilik 4 farklı konuta ait oldukları ve bu konutların güneybatıda bulunan sokak cephelerini oluşturdukları söylenebilir (Fig. 10). Yapı inşa malzeme ve tekniği nedeniyle bu duvarların Doğu Roma dönemine ait oldukları anlaşılmaktadır ${ }^{8}$.

\section{Anıtsal Yapı ve Cadde}

G - F / XIII - XIV sektör sınırlarında yer almaktadır (Fig. 2). Akropolisin kuzeybatısındaki dik

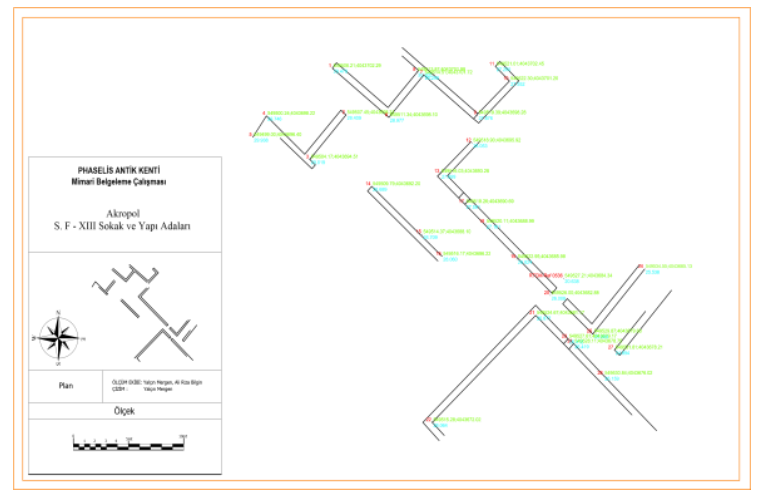

Fig. 10. Akropolis, F - XIII Sektöründe Tespit Eedilen Mekânlar ve Muhtemel Sokak

7 Bu görüş Phaselis antik kenti su sistemlerini ve sarnıçlarını çalışmakta olan ekip üyesi Sayın Mehmet Kürkçü ile görüşülmüş ve teyit edilmiştir.

8 Akropolisin konut alanı olduğu ilk defa Beaufort tarafından (Beaufort 1818, 56, 60), Doğu Roma Dönemi'nde konut alanlarına sahip olduğu bilgisi ise ilk defa Schäfer tarafından verilmiştir (Schäfer 1981, 81). 
eğimli yamacın hemen kenarında inşa edilmiş olan cadde, erken ve geç dönemlerde kullanıldığı anlaşılan anıtsal erken dönem yapısına paralel olarak kuzeydoğu - güneybatı yönünde uzanmaktadır (Şek. 5). Bu yön caddenin Phaselis tiyatrosu ile de ilişkili olabileceğini düşündürmektedir. Caddenin günümüzde bitki örtüsü ve yıkıntılar nedeniyle sadece 32 metrelik bölümü izlenebilmektedir. Görülebilen bu bölümde erken dönem duvarlarına paralel olarak büyük boyutlu bloklarla düzenlenmiş bir stylobat, stylobat çevresinde ise devrilmiş durumda sütunlar bulunmaktadır. Bu durum caddenin sınırlarını batıda, bosajlı ve büyük boyutlu blokları nedeniyle erken döneme tarihlenebilecek olan anıtsal yapı; doğuda ise sütunlu bir düzenlemenin oluşturduğunu göstermektedir. Bu nedenle 4,5 m genişliğindeki caddenin doğu kenarında

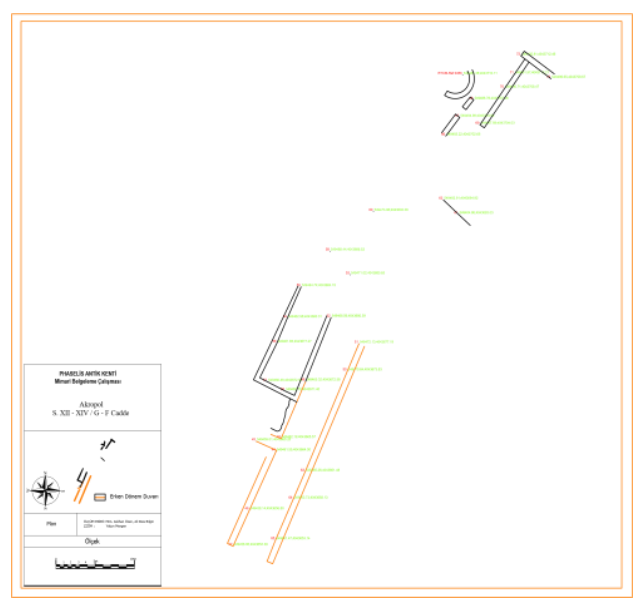

Fig. 11. Akropolis Batı Yamaç Erken Dönem Sütunlu Düzenlemesi ve Geç Döneme Ait Muhtemel Sokak bir stoası olduğunu söylemek yanlış olmayacaktır. Bununla beraber net bilginin kazı çalışmaları ile elde edilebileceği açıktır.

Cadde ve anıtsal yapının Doğu Roma döneminde de kullanıldığı malzeme - teknik açıdan farklılıklar gösteren duvarların çevrede yoğun olmasından ve özellikle caddenin kuzeyinde yer alan düzenlemenin mekânsal dönüşüme neden olmasından dolayı söylemek mümkündür.

\section{$4 n^{\circ}$.'lu Kilise}

Söz konusu kilise 1968 ile 1970 yılları arasında Schlager ve Schäfer başkanlıklarında yürütülen çaIışmalar sırasında görülmüş ve belgelenmiştir ${ }^{9}$ (Fig. 14). Bu yıllarda Phaselis'te yapılan çalışmaların akropoliste yoğunlaşamadığı anlaşılmaktadır. Bu nedenle olsa gerek, $4 \mathrm{n}^{0}$.'lu kilisede yapılan plan çalışmasında da bazı eksikler olduğu görülmektedir. Bu nedenle yapı ekibimiz tarafından tekrar ele alınmıştır.

$4 n^{0}$.'lu kilise akropolis yarımadasının güneybatı ucunda ve $\mathrm{G}-\mathrm{XV}$ sektörünün de güneybatı köşesine çok yakındır (Fig. 2). Akropolis tepesinin

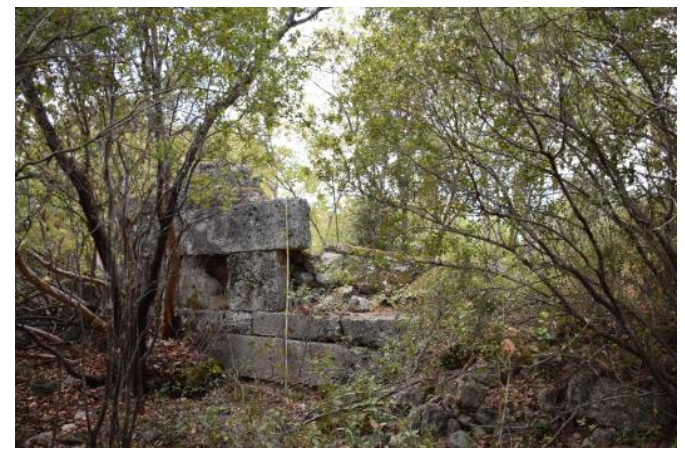

Fig. 12. Akropolis Batı Yamaç Erken Dönem Sütunlu Düzenlemesine Ait Anıtsal Duvar güneybatısında izlenen ve direkt olarak denizden kaya duvarı benzeri yükselen yarların hemen kenarında bulunmaktadır. Akropolis tepesinin bu bölümü deniz seviyesinden 24 m yüksekliktedir. Yapı akropolis tepesi açısından görece oldukça geniş bir düzlük üzerine inşa edilmiştir (Fig. 1, 2) ve inşa edildiği düzlüğü 2014 yılı çalışmalarında tespit edilen ve $1 n^{\circ}$. ile adlandırılan, şimdilik Phaselis'in Doğu Roma Dönemi'ne tarihlenen en büyük boyutlu bazilikası ile paylaşmaktadır ${ }^{10} .4$ $n^{0}$.'Iu kilisenin hemen batısında yer alan $1 n^{0}$.'Iu kilise ile organik ilişkisi olduğu hem yakınlıkları hem de iki yapının arasında izlenebilen duvar kalıntıları nedeniyle varsayılabilir gözükmektedir

9 Schäfer 1981, tafel 57 - 3.

10 Yapının ön değerlendirmesi için bkz. Mergen 2015, 282 - 285. 
(Fig 2). Bu düşüncenin doğruluğu ancak sistematik kazıların sonuçlarına dayalı olarak sınanabilir niteliktedir.

$4 n^{0}$.'lu kilise kuzeybatı - güneydoğu yöneliminde inşa edilmiştir. Yapının naosu, 'düzensiz kareye yakın dikdörtgen' biçime sahiptir. Bu nedenle aksiyel ölçülerde de düzensizlik izlenmektedir.

Bununla beraber yapı, ana akslarda duvar kalınlıkları ile birlikte kuzeybatı - güneydoğu aksında 17 m kuzeydoğu güneybatı ana aksında ise ortalama genişliği $12 \mathrm{~m}$ olarak ölçülmektedir ${ }^{11}$. Bu ölçüler Schäfer'in eserinde naos için verdiği ölçülerle örtüşse de ${ }^{12}$ yapı, aynı çalışmada 'düzgün kareye yakın dikdörtgen' biçimde plana yansıtılmıştır (Fig. 14). 2016 yılı çalışmaları ile varlığı tespit edilen atrium ve atriuma bağı ıan mekânla birlikte kilisenin, 29,70 × 20,35 m ebatlarında bir alan üzerine yerleştiği anlaşılmaktadır.

4 n'.'lu kilise naos ve atrium dışında yan mekânlara da sahiptir. Yukarıda da belirtildiği gibi 'düzensiz kareye yakın dikdörtgen' biçimde düzenlenmiş bir naosa sahip, üç nefli 'helenistik bazilikal' plan şemasına uygun olarak inşa edilmiş, küçük boyutlu bir yapıdır ${ }^{13}$. Naosun giriş ve apsis cephelerinde kuzey ve güneyde görülen, taşıyıcı ve stylobat aksında olması gereken dikdörtgen kesitli payandalar, yapının bu plan şemasında inşa edildiğini kanıtlamaktadır (Fig. 15, 16). Yapının apsisi içten ve dıştan yuvarlak ve çok merkezli yay biçiminde, dıştan vurguludur. Apsis duvarı alt seviyelere kadar yıkıldığından burada olması muhtemel pencere açıklıkları hakkında bir şey söylemek mümkün değildir (Fig. 18).

Naos içinde dikkate değer bir husus da, güney nefe bağlantılı olduğu anlaşılan ve dikdörtgen yassı bloklar kullanılarak imal edilmiş düzenlemedir (Fig 16, 20). İşlevi konusunda yüzeyde elde edilen bulgular çerçevesinde bir öneri getirmek mümkün değildir. Ayrıca gene naos içinde görülen ve yapının inşa malzemesi ile tezat oluşturan büyük boyutlu bloklar da düşündürücüdür. Zira kuzey nef duvarına yakın konumlanan bu blokların pozisyonları dağılmış bir düzenleme çağrışımı yapmaktadır (Fig. 16, 19, 20).

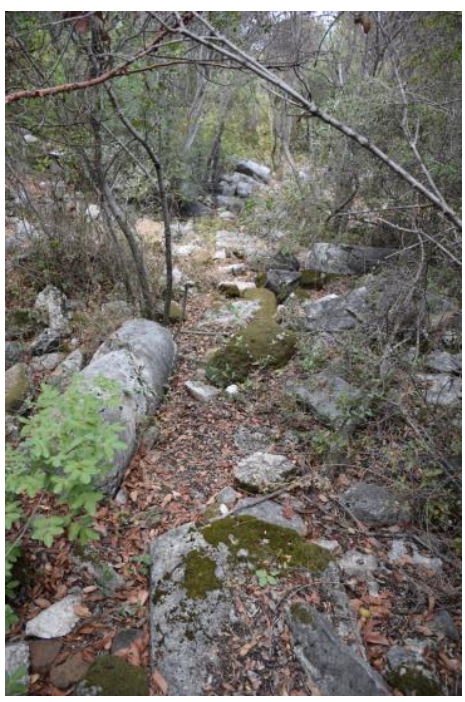

Fig. 13. Akropolis Batı Yamaç Erken Dönem Sütunlu Düzenlemesine Ait Sütunlar ve Stilobat

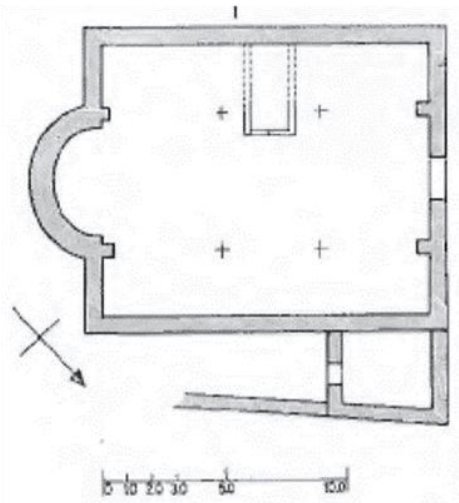

Fig. 14. $4 \mathrm{n}^{\circ}$.' Iu Kilisenin 2016 Yılı Öncesindeki Bulgulara Dayalı Planı (Schäfer 1981, tafel 57 - 3)

11 Ayaş, Tapınak Kilisesi (Hill 1996, 92, Fig. 11) ve Tapureli, B Kilisesi (Hill 1996, 247, Fig 52) ölçüleri ve mekansal karakterleri açısından $4 \mathrm{n}^{0}$.'lu kilise ile benzerlik göstermektedir.

12 Schäfer 1981, 122.

13 Üç nefli helenistik plan şeması Lykia Bölgesi'nde oldukça yaygındır. Bununla beraber Phaselis $4 n^{\circ}$.'lu kilise sadece plan şeması değil ama aynı zamanda naos ebatları ve proporsiyonal bütünlük açısından da değerlendirilmek durumundadır. Yapının atrium ve naosu kareye yakın dikdörtgen, eş birimli yapısal bir özellik sunmaktadır. Oysaki Lykia Bölgesi'nde Rhodiapolis (Tiryaki 2012, 510), Andriake (Tekinalp 2000), Olympos (Gökalp - Yıldırım 2010, 367-387; Mergen 2011) ve başka kentlerdeki birçok örnekte olduğu gibi bazilikal plan şeması proporsiyonları açısından tamamen dikdörtgen olarak uygulanmıştır. 4 n ${ }^{0}$.'lu kilisede olduğu gibi, kareye yakın dikdörtgen mekânsal düzenleme Ova Büyük Avşar Bazilikası'nda (Altripp 2008, Abb. 1) olduğu gibi sınırlı sayıdadır. 
Ana mekânın günümüze ulaşan duvarlarında pencere açıklıklarına dair bir ize rastlanamadığı gibi, yapının taşıyıcı sistemine dair de bir bulgu elde edilememiştir. Bununla beraber, yüzeyde herhangi bir sütun kalıntısının olmaması ve Phaselis $2 n^{0}$.'lu kilisenin taşıyıcı sisteminin paye olmasından yola çıkarak; $4 \mathrm{n}^{0}$.'Iu kilisenin taşıyıcı sisteminin de paye olduğu önerilebilir.

Naosun kuzeyinde birbiriyle bağlantılı iki mekân daha bulunmaktadır (Fig. 15, 16). Duvarların yer yer yıkık, çoğunlukla da yıkıntı molozu altında kalması nedeniyle; ana mekân ve birbirleri ile olan organik bağlantıyı sağlayan kapı açıklıkları görülememektedir. Bununla beraber kuzey nef duvarının ortasında görülen yıkıntı ve yıkıntıdan kaynaklı açıkığın önünde yer alan büyük bloklardan yola çıkarak, naos ve kuzey yan mekânlar arasındaki bağlantıyı sağlayan kapının burada olduğunu varsaymak mümkündür (Fig. 16, 19)

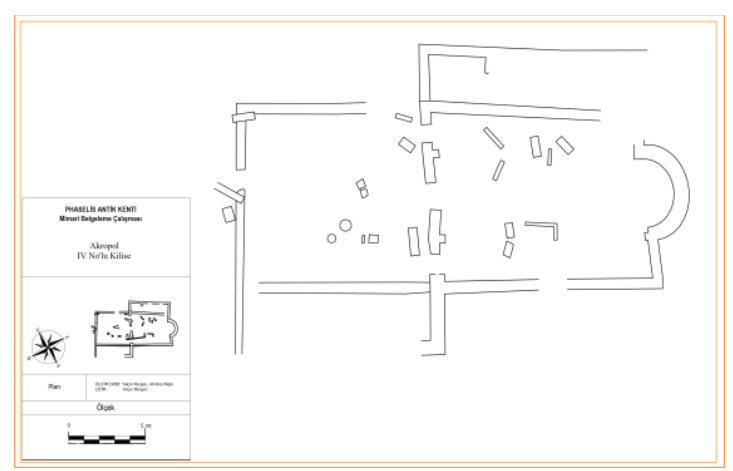

Fig. 15. Akropolis G- XV ve GXVI Sektöründe Yer Alan $4 n^{\circ}$.'Iu Kilise, Plan

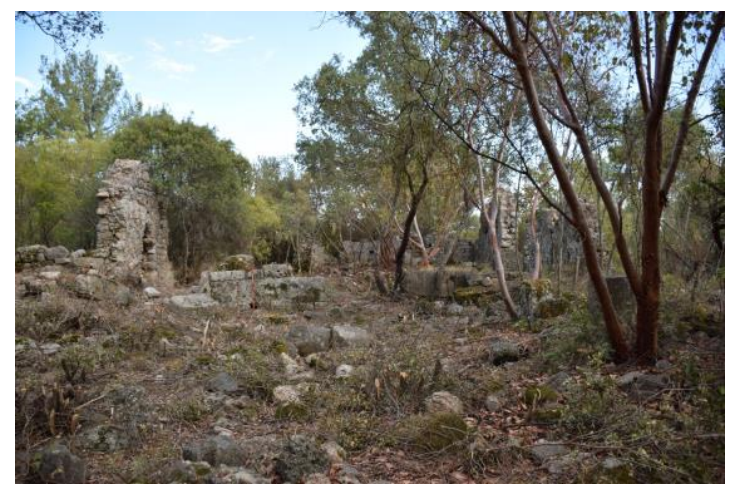

Fig. 17. Akropolis G- XV ve GXVI Sektöründe Yer Alan 4 n.'lu Kilise, Avlu ve Naos, Doğuya Bakış

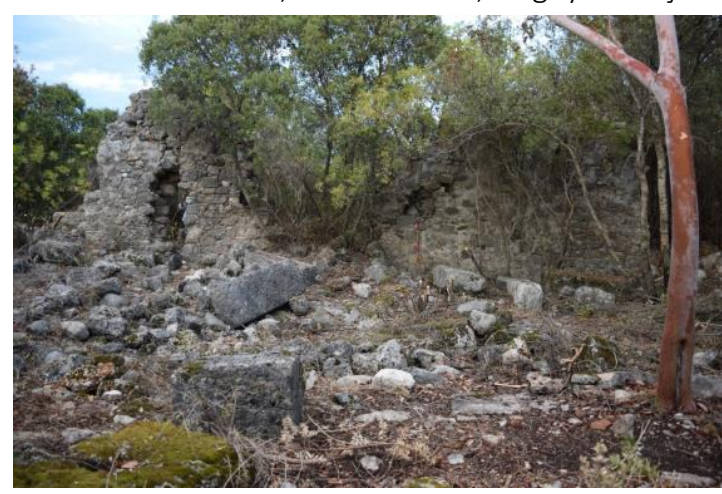

Fig. 19. Akropolis G- XV ve GXVI Sektöründe Yer Alan 4 n.'lu Kilise, Naos, Kuzey Duvar

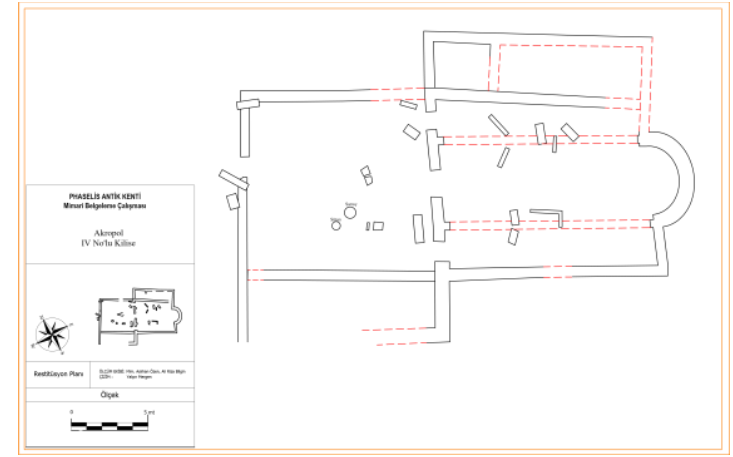

Fig. 16. Akropolis G- XV ve GXVI Sektöründe Yer Alan $4 n^{\circ}$.'lu Kilise, Restitüsyon Planı

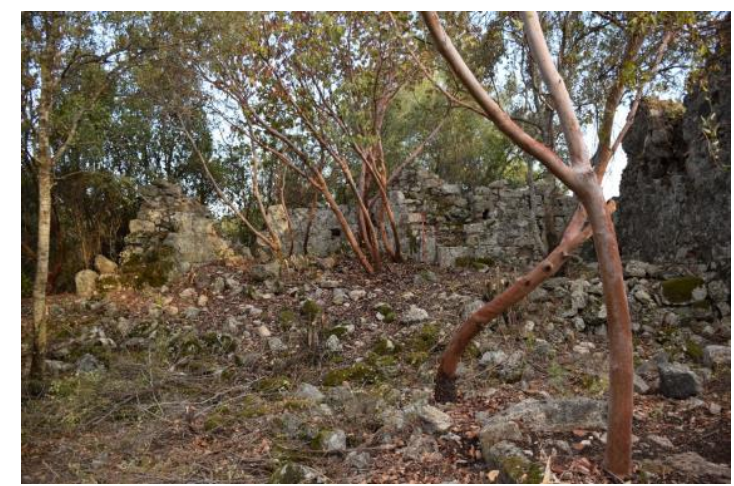

Fig. 18. Akropolis G- XV ve GXVI Sektöründe Yer Alan 4 nº'Iu Kilise, Apsis İç Cephesi, Doğuya Bakış

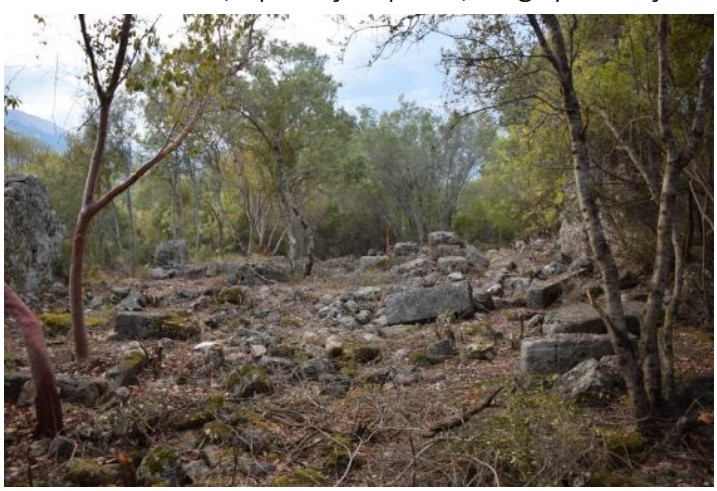

Fig. 20. Akropolis G-XV ve GXVI Sektöründe Yer Alan $4 \mathrm{n}^{0}$.'lu Kilise, Naos ve Avlu, Batıya Bakış 
Naosun batısında naosla yaklaşık aynı ölçülere sahip bir atrium bulunmaktadır (Fig. 16). Atriumdan naosa geçiş üç kapı açıklığı ile sağlanmaktadır. Atrium içinde olasılıkla çevresinde özel bir düzenleme ile sınırlanmış olduğu çevresindeki devşirme sütunlara dayalı olarak anlaşılan büyük boyutlu bir sarnıç bulunmaktadır. Atriumun duvarları günümüze sağlam ulaşamadığı (Fig. 17) ve çoğunlukla da yıkıntı molozu altında kaldığı için, atriuma giriş ve çıkış sağlayan açıklıklar görülememektedir. Ayrıca ana mekânın kuzeyinde görülen ek mekânların dışında, avlunun güneyinde de olasılıkla avluyla organik bağlantısı olduğunu varsayabileceğimiz bir yan mekân daha tespit edilmiştir (Fig. 15, 16).

\section{Phaselis Teritoryumu Doğu Roma Çalışmaları}

2016 yılı çalışma sezonunda, Phaselis kent merkezi dışında da yukarıda belirtilen nedenler ve amaçlar doğrultusunda çalışmalar yürütülmüştür. Bu çalışmalardan ilki Antalya Altınyaka Bucağı 363437 N, 302520 E koordinatlarında bulunan bir yapı kalıntısında gerçekleştirilmek üzere planlanmışsa da, ne yazık ki yapının çok yakın bir zamanda bulunduğu arazideki teras çalışmaları sırasında tamamen yok edilmesi nedeniyle yapılamamıştır.

Çevrede görülen sadece fotoğraflanarak belgelenebilen mimari ve mimari plastik kalıntılar nedeniyle yapının Erken Doğu Roma Dönemi'ne tarihlenmesi muhtemel anıtsal boyutlarda bir kilise olduğu anlaşılmaktadır. Yapının bulunduğu terasın yaklaşık doğusunda yer alan bir taş yığını içinde ve etrafında zeytinyağı presine ait olduğu anlaşılan iki adet eser dışında sütun, yassı pencere payesi, sütun ve yassı payelere ait başlıklar, arşitrav ve baluster parçaları görülmüştür. Çevreye küreyici iş makineleri tarafından saçılan kaliteli kaplama parçalarına bağlı olarak da yapının geometrik paternli opussektile yer döşemeleri ile zenginleştirildiği gözlemlenmiştir. Yapıdan geriye kalan mimari ve in situ tek veri olasılıkla yapının güneybatı köşesidir bu da yaklaşık 1,50 m yüksekliğinde ve 0,70 m genişliğinde iki duvar parçası olarak gözlemlenmiştir.

Bir alt terasta yer alan evin bahçesi ve su basman duvarlarında yapı yıkıntısında görülen mimari plastiklerle aynı işlev, kalite ve üslupta mimari plastik malzeme ile karşılaşılmıştır. Bunların arasında kaliteli işçilik gösteren blok taşlardan üretilmiş olduğu anlaşılan kemerlere ait kemer çatalı, kemer omuzlaması parçaları, çifte sütunce başlıkları gibi öğelere yoğun miktarda rastlanmıştır. 


\section{BİBLIYOGRAFYA}

Altripp 2008

Arel 1990

Arel 1993

Arslan - Tüner Önen 2015a

Arslan - Tüner Önen 2015b

Arslan - Tüner Önen 2016a

Arslan - Tüner Önen 2016b

Beaufort 1818

Gökalp - Yıldırım 2010

Hill 1996

Kolb 1996

Kolb 1998

Konency 1997

Mcnicoll - Winikoff 1983

Mergen 2011

Mergen 2015

Mergen - Bilgin 2016

Schäfer 1981

Tekinalp 2000

Tiryaki 2012
M. Altripp, "Die Kirchen in und bei der Siedlung XLII von Büyük Avsar (Zentrallykien)". Hg. F. Kolb, Lykische Studien 8: Keramik, Münzen, Kirchen und Wirtschaftskomplexe des zentrallykischen Yavu-Berglandes (Gebiet von Kyaneai) (Tübinger Althistorische Studien 4). Bonn (2008) 173-182.

A. Ayda. "Foça Bağ Evleri ve Kule Ev Geleneği". AST VII (1990) 43-71.

A. Ayda "Foça Bağ Evleri ve Kule Ev Geleneği". Egemimarlık 10/3 (1993) 37

M. Arslan - N. Tüner Önen, Phaselis ve Teritoryumu Yüzey Araştırması 2014, Anmed 13 (2015) 198-2017.

M. Arslan - N. Tüner Önen, 2014 Yılı Phaselis Antik Kenti ve Teritoryumu Yüzey Araştırması, AST 33/2 (2015) 69-80.

M. Arslan - N. Tüner Önen, Phaselis ve Teritoryumu Yüzey Araştırması 2015, Anmed 14 (2016) 236-246.

M. Arslan - N. Tüner Önen, 2015 Yılı Phaselis Antik Kenti ve Teritoryumu Yüzey Araştırması, AST 34/1 (2016) 355-368.

F. Beaufort, Karamania, A brief Description of the South Coast of Asia Minor. London 1818.

Z. D. Gökalp - Ş. Yıldırım, "Lykia Olympos’unda Bir Restitüsyon Denemesi". ADALYA XIII (2010) 367-387.

S. Hill, The Early Byzantine Churches of Cilicia and Isauria. Variorum 1996.

F. Kolb (ed.) Asia Minor Studien Band 24: Lykische Studien 3: Die Siedlungskammer von Kyaneai in Lykien: Bericht uber Feldforschungen im Yavu-Bergland im Sommer 1992.

F. Kolb, "Kyaneai Yüzey Araştırmaları". AST XV (1998) 345- 364.

A. Konency, Turmgehöfte in Zentral und Ostlykien. Wien 1997.

Mc Nicoll - T. Winikoff, "A Hellenistic Fortress in Lycia-The Isian Tower?". AJA 87/ 3 (1983) 311-323.

Y. Mergen, Olympos Antik Kenti'nin Orta Çağ Dönemi Dokusu ve Likya Bölgesi Açısından Önemi. Yayımlanmamış Doktora Tezi, Ege Üniversitesi, İzmir 2011.

Y. Mergen, "2014 Yılı Çalışmaları Işı̆̆ında Phaselis Antik Kenti'nin Geç Antik ve Ortaçağ Mimarisi ile Kentsel Yapısı". Phaselis I (2015) 273-285. http://dx.doi.org/10.18367/Pha.15014

Y. Mergen - A. R. Bilgin, "2015 Yılı Çalışmaları Kapsamında Phaselis Antik Kenti Akropolündeki Doğu Roma Yerleşimine Ait İzler". Phaselis II (2016) 123-132. http://dx.doi.org/10.18367/Pha.16007

J. Schäfer, Phaselis. Beiträge zur Topographie und Geschichte der Stadt und ihrer Häfen. Tübingen 1981.

V. Macit Tekinalp, Geç Antik Dönem Sonrasında ve Ortaçağ'da (MS. 4. 14. y.y.) Andriake Kenti. Yayımlanmamış Doktora Tezi, Hacettepe Üniversitesi, Ankara 2000.

A. Tiryaki, "Rhodiapolis Piskoposluk Kilisesi'ne Ait Bir Grup Korkuluk Levhası". OLBA XX (2012) 494-514. 